\title{
The antagonism between Trichoderma viride and other pathogenic fungal strains in Zea mays
}

\author{
Bouziane Z., ${ }^{* 1}$ Dehimat L., ${ }^{2}$.Abdel aziz W., ${ }^{2}$ Benabdelkader M., ${ }^{3}$ Kacem chaouche $\mathrm{N}^{2}$ \\ Laboratory of Applied Mycology Department of Biology and Ecology \\ University Mentouri Constantine - Algeria
}

\begin{abstract}
Fungi such as Trichoderma and Gliocladium associated with parasitic behavior manifested by a coil around the hyphae of fungi filaments. This study showed the antagonistic effect of Trichoderma viride against the different fungal isolates infecting the plant Zea mays. The strain of Trichoderma viride was isolated from Jijel soil character by humid climate. By different organs (roots, stems and leaves) of plant Zea mays have been isolated 28 fungal strains belonging to 17 genus: Absidia, Alternaria, Aspergillus, Botrytis, Cladosporium, Epicoccum, Fusarium, Geotrichum, Melanconium, Monileilla, Penicillium, Phoma, Pythium, Scopulariopsis, Scytalidium, Trichoderma and Ulocladium. The test of direct confrontation between Trichoderma viride and fungal isolates was made on PDA. The competitive action of Trichoderma viride on the pathogen in the presence or absence of zone of inhibition was seen in this test. The growth rate of fungal isolates and Trichoderma viride has been determined. Trichoderma viride reached the confluence of the Petri dish four days after sowing, so that different fungal isolates occupy a surface of $29 \%$ to Fusarium roseum, $13 \%$ for Epicoccum sp2, 44\% for Epicoccum sp3, $21 \%$ for Monileilla sp, 15\% for Absidia sp and 6\% for Trichoderma sp2 which corresponds to an inhibition of mycelia growth of fungal isolates tested.
\end{abstract}

Keywords: confrontation, Trichoderma viride, pathogen, competition, biocontrol

\section{INTRODUCTION}

Fungi are among the pathogens that affect foliage plants, causing diseases. A large number of fungi belonging to phycomycetes, ascomycetes and deuteromycetes are responsible for the majority of diseases (wilt, rot and seedlings-off) (Chase 1987).

Several mechanisms are important in antagonistic interactions, including mycoparasitism and competition for substrates and sites of infection (Benitez and al. 1998). The fungal strains for biological control against plant pathogens must have an activity that is manifested by the ability to use the same Trichoderma community resources that pathogenic fungi, Trichoderma, but uses this mode of action primarily to occupy the premises before the arrival of events. (Gaetan LeFloch and al. 2006)

In order to find alternative control against the phytopathogens. Our study is to demonstrate the capacity and activity of Trichoderma viride isolated from Jijel soil character by humid climate where we are cultivated Zea mays.

The capacity of Trichoderma viride is translated by the inhibition of growth of many fungal strains isolated from different organs (roots, stems and leaves) of the plant.

\section{MATERIALS AND METHODS}

Sampling: Plants of maize (Zea mays), exist in the region of Jijel showing unhealthy symptoms were completely removed (ex: wilting). The plants have been wiped from moisture, placed in sterile paper bags, and tacked in laboratory. The analysis in leaves, stems and roots infected was realized by the method of (Davet and Rouxel 1997). Various parts of plant have been washed thoroughly with running water, cuted into pieces and placed in becher containing $0.1 \% \mathrm{HgCl}_{2}$ for 2 minutes to disinfect surface and then washed three times in succession with distilled water, and finally dried with sterile paper Wattman sterile. These fragments were placed on PDA in Petri dishes (potato 200g, $20 \mathrm{~g}$ glucose, $20 \mathrm{~g}$ agar and 1000ml distilled water, (Guraud 1998) and incubated at a temperature of $25 \mathrm{c}^{\circ}$ for five days. After incubation colonies of different fungi grow on culture medium.

Purification of isolates: In order to purifite the purification of fungal isolates, we applied the dilution method which involves taking, using a sterile 
Agric. Biol. J. N. Am., 2011, 2(4): 584-590

platinum wire, friction from the Petri dish containing several colonies and that we putted in test tubes containing $10 \mathrm{ml}$ sterile saline. After stirring, we oriented to prepare decimals dilutions until obtained a single spore / $\mathrm{ml}$. Spores (monospores) were seeded in Petri dishes containing water agar (20g agar agar and 1000ml distilled water (Guraud 1998). After incubation in $18 \mathrm{~h}$ at $25 \mathrm{c}{ }^{\circ}$ the cutting Mycelia searched using a microscope to be inoculated in a Petri dish containing PDA (Botton and al.1985). Identification: Microscopic examination of fungal isolates permitted the identification of the micro flora, the identification of fungal species was based on: micro-morphology, aspect and structure of conidies according (Botton and al. 1985).

The pathogen: The pathogen used is represented by fungal strains isolated from different organs (roots, stems and leaves) of maize plant infected in Jijel town (North - East) of Algeria. The different fungal isolates were identified in the laboratory of Applied Mycology. The university of Mentouri, Constantina town and conserved for future use.

The antagonistic agent: We used the strain of Trichoderma viride isolated from soil of the Jijel town, where we were grown the corn plant. Trichoderma viride has been identified in the laboratory of Applied Mycology. University. Mentouri. Constantine. Algeria.

\section{METHODOLOGY}

The antagonist activity on PDA of Trichoderma viride was studied by the method of (Comporta 1985); Patel and Brown 1969). We used the method of direct confrontation; this method is consisted to put on the same Petri dish containing $15 \mathrm{ml}$ of PDA medium, two agar pellets (8 $\mathrm{mm}$ diameter) one strain of Trichoderma viride and other agent pathogen are positioned along a diametrical axis $3 \mathrm{~cm}$ away. The control is presented only by the pathogen; incubation is performed at $25 \mathrm{c}^{\circ}$ for six days in the dark.

The evolution of mycelial growth is performed every 24 hours by measuring the diameter of the colony of the pathogen and the antagonist. The valuation of inhibition by Trichoderma viride is estimated by calculating the percentage inhibition of mycelia growth by the following formula: $1 \%=(1-\mathrm{Cn} / \mathrm{Co})$ x100)

Cn is the average diameter of colonies of pathogen in the presence of the antagonist and Co the average diameter of colonies of control.

\section{RESULTS AND DISCUSSION}

All samples analyzed were contaminated with mold. Several fungi have been isolated and identified. Indeed, 28 fungal isolates were isolated belonging to 17 genus: Absidia, Alternaria, Aspergillus, Botrytis, Cladosporium, Epicoccum, Fusarium, Geotrichum, Melanconium, Monileilla, Penicillium, Phoma, Pythium, Scopilariopsis, Scytalidium, Trichoderma and Ulocladium. The results are presented in Table 1.

The majority of detected fungal isolates are principally a field mold, with variable infected percentage $3,57 \%$ to Verticillium sp, $7.14 \%$ Fusarium sp, $10.71 \%$ to Phoma sp 3, 57\% to Botrytis sp, $10.71 \%$ to Epicoccum sp, $10.71 \%$ to Alternaria $s p, 7.14 \%$ to Trichoderma $s p, 3.57 \%$ Pythium $s p$ with and $7.14 \%$ to Penicillium $s p$. Other molds are relatively less frequent: Absidia $s p$, Aspergillus $s p$ and Melanconium $s p$ with $3.57 \%$ for each isolate.

The isolation from the roots is revealed the presence of three genus Trichoderma, Pythium and Verticillium. The presence of Trichoderma and Pythium on root explained by the two nonpathogenic species and by humidity and water is very high in the roots. Pythium was present a nombrous interested characters for a biological control agent (Le Floch and al.2003a); (Roquebert 1996). It is known to reduce the severity of the pathogen agent, but its survival and propagation in culture is also promoted by the production of oospores. Pythium may be inter in competition with the endogenous flora (Gaetan Le Floch and al. 2006). Several researchers have reported that Trichoderma species are characterized by their mode of action primarily to occupy the site before the arrival of phytopathogenic, and have a good activity mycoparasitic and competitive ability (Chet 1987). Trichoderma is a natural fungus that colonizes the soil and plant roots before phytopathogenic, it can play a role in the health of plants (Gams and Bissett 1998). Furthermore, to level the stem were encountered four different genus: Absidia, Alternaria, Fusarium and Monileilla.

On the leaves were isolated twenty fungal strains belonging to 12 genus: Alternaria, Aspergillus, Botrytis, Cladosporuim, Epicoccum, Fusarium, Geotrichum, Melanconium, Penicillium, Pythium, Scytalidium and Ulocladium at variable frequencies. Fusarium sp, Epicoccum sp, Phoma sp and Ulocladium $s p$ are among the leaf parasites encountered on maize (Frisvad and Samson 1991). Generally Fusarium, Ulocladium and Epicoccum attack all plant parts (roots, stems and leaves), they are destroyed. 
Christensen (1957) has been reported that fungi invade grain fields under development on the growing plant or after the seeds have matured. At this stage, the water content of seeds is high and their tissues are active. The results of the mycological analysis showed a clear dominance seems to be favored by moisture content in equilibrium with a relative humidity of $90 \%$ or more (Bouchet and al. 2005).

The dominance of the genus Fusarium, Phoma and Ulocladium contaminating flora in cereals has been reported in several studies (Christensen 1964; Dhingra and Sinclair 1995; Gevers 1975; Marjoline and al.2002). Thus, species of Aspergillus and Penicillium mold are considered storage. The rate of contamination by the two previous genus has revealed the length of storage and high humidity of the grain (Champion 1997; Prusky and Yakoby 2003). The other strains isolated from samples analyzed belong to the genus: Epicoccum, Cladosporium, Absidia, Monileilla, Scytalidium and Geotrichum are naturally present on crops in fields and in soil (Christensen and al. 1977).

The results of isolation taken from each organ of the plant show that the leaves are the most contaminated with a percentage of $71.42 \%$ followed by the roots and stems with $14.28 \%$ for each in figure 1.

The results of antagonism between Trichoderma viride and different phytopathogens agent infected plant maize, showed a significant reduction in mycelial growth of fungal colonies of different isolates face the strain Trichoderma viride compared to the control table 2. The colony growth of Monileila $s p$, Absidia sp, Phoma sp2, Penicillium sp and Botrytis $s p$, is stopped on the third days of confrontation, the Cladosporium sp, Geotrichum sp and Ulocladium $s p$ is stopped during the fourth days when these isolates are in contact directly with Trichoderma viride. After six days the colony of Trichoderma viride completely covers the colonies of these parasites on which it sporulated figure 2. Trichoderma viride showed a power antagonist which is the ability to remotely stop pathogen development Trichoderma sp2, Verticillium sp.

According, Antel and al. (2000), the test of confrontation in vitro exerted by Trichoderma species showed an increase in the colony and the secretion of extracellular enzymes, which destroys the membranes of pathogen hyphae.

These results showed a slowing of mycelial growth of different isolates. Indeed, the average diameter of colonies of Alternaria sp1, Epicoccum sp3, Epicoccum sp2 and Epicoccum sp1, Trichoderma viride faces respectively to $26.83 \mathrm{~mm}, 26.25 \mathrm{~mm}$, $37.25 \mathrm{~mm}$ and18, $25 \mathrm{~mm}$ instead to $40.33 \mathrm{~mm}, 46.75$ $\mathrm{mm}, 42.41 \mathrm{~mm}$ and $22.41 \mathrm{~mm}$ in the control. The inhibition of growth is about $34 \%$ to Alternaria sp1, $44 \%$ to Epicoccum sp3, $13 \%$ to Epicoccum sp2 and 19\% to Epicoccum sp1. Trichoderma viride reached the confluence of the Petri dish, after three days of incubation, the box is almost invaded by Trichoderma viride, whereas colonies of different isolates occupy a very small area, which corresponds to an inhibition of mycelia growth. In contrast we note the mycelial growth continues to evolve with isolates Scytalidium sp; Ulocladium sp4; Pythium s; Phoma sp3 and Melanconium sp figure 3

Isolates Scytalidium sp; Ulocladium sp4; Pythium sp, Phoma sp3 and Melanconium sp show significant resistance to the substances produced by Trichoderma viride with an average diameter of the colony, respectively, $48.46 \mathrm{~mm} ; 49.33 \mathrm{~mm} ; 45.5 \mathrm{~mm}$; $66.5 \mathrm{~mm}$ and $53.83 \mathrm{~mm}$, compared with the control $75.83 \mathrm{~mm} ; 70.91 \mathrm{~mm} ; 60.66 \mathrm{~mm} ; 74.25 \mathrm{~mm}$ and $72.66 \mathrm{~mm}$ figure 4.5 .

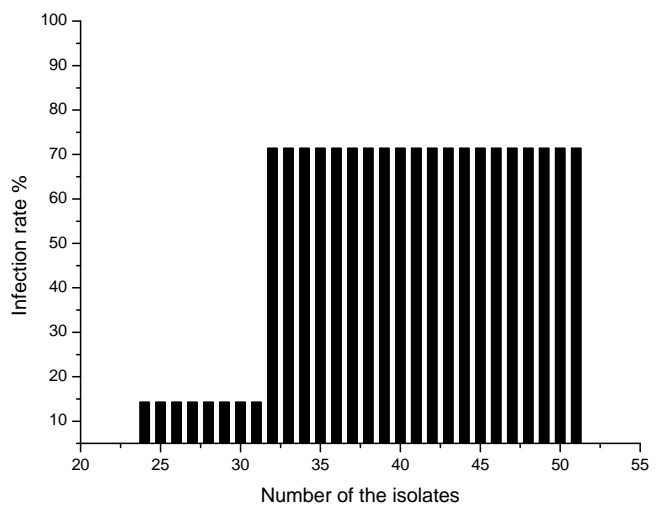

Fig 1: Percentage of infection of various organs of the maize plant 
Agric. Biol. J. N. Am., 2011, 2(4): 584-590

Table 1: Origin of isolates and the infection rate

\begin{tabular}{|c|c|c|c|}
\hline No. isolates & Fungal isolates & Source & Infection \% \\
\hline 24 & Trichoderma sp2 & roots & $14.28 \%$ \\
\hline 25 & Trichoderma sp3 & & \\
\hline 26 & Pythium sp & & \\
\hline 27 & Verticillium $s p$ & & \\
\hline 28 & Alternaria alternata & stems & $14.28 \%$ \\
\hline 29 & Monileilla sp & & \\
\hline 30 & Absidia sp & & \\
\hline 31 & Fusarium roseum & & \\
\hline 32 & Penicillium frequentans & leaves & $71.42 \%$ \\
\hline 33 & Phoma sp2 & & \\
\hline 34 & Penicillium $s p$ & & \\
\hline 35 & Ulocladium sp2 & & \\
\hline 36 & Botrytis sp & & \\
\hline 37 & Cladospoium sp1 & & \\
\hline 38 & Ulocladium sp3 & & \\
\hline 39 & Phoma sp3 & & \\
\hline 40 & Alternria alternata & & \\
\hline 41 & Phoma sp4 & & \\
\hline 42 & Aspergillus niger & & \\
\hline 43 & Epicoccum sp1 & & \\
\hline 44 & Fusarium sp2 & & \\
\hline 45 & Epicoccum sp2 & & \\
\hline 46 & Geotrichum sp & & \\
\hline 47 & Scytalidium sp & & \\
\hline 48 & Ulocladium sp4 & & \\
\hline 49 & Melanconium sp & & \\
\hline 50 & Epicoccum sp3 & & \\
\hline 51 & Alternaria sp1 & & \\
\hline
\end{tabular}

Table 2: Average diameter $(\mathrm{mm})$ of colonies of Trichoderma viride pathogenic face and the importance of inhibition rate

\begin{tabular}{|c|c|c|c|c|}
\hline No. strains & $\begin{array}{l}\text { average diameter of } \\
\text { pathogen }(\mathrm{mm})\end{array}$ & $\begin{array}{l}\text { average diameter of } \\
\text { control }(\mathrm{mm})\end{array}$ & $\begin{array}{l}\text { percentage } \\
\text { inhibition\% }\end{array}$ & $\begin{array}{l}\text { average diameter of } \\
\text { antagonist }(\mathrm{mm})\end{array}$ \\
\hline R24 & 45.25 & 47.83 & 6 & 58.75 \\
\hline R25 & 44.83 & 57.16 & 22 & 46.83 \\
\hline R26 & 45.5 & 60.66 & 25 & 48.91 \\
\hline R27 & 24.33 & 39 & 38 & 63.75 \\
\hline T28 & 18.66 & 23.58 & 21 & 55.75 \\
\hline T29 & 10.5 & 13.25 & 21 & 64.58 \\
\hline T30 & 24.41 & 28.41 & 15 & 48.41 \\
\hline T31 & 25 & 34.83 & 29 & 60.91 \\
\hline F32 & 41.16 & 56.58 & 28 & 41.58 \\
\hline F33 & 28.91 & 37.83 & 24 & 61.5 \\
\hline F34 & 17.83 & 24.58 & 28 & 55.5 \\
\hline F35 & 21.41 & 31.41 & 33 & 35.16 \\
\hline F36 & 15.16 & 16.83 & 10 & 59.5 \\
\hline F37 & 20.41 & 26.5 & 23 & 44.91 \\
\hline F38 & 64.41 & 73.25 & 13 & 57.25 \\
\hline F39 & 66.5 & 74.25 & 11 & 44 \\
\hline F40 & 14.66 & 16.5 & 12 & 52 \\
\hline F41 & 39.08 & 54.81 & 29 & 60.16 \\
\hline F42 & 24.08 & 28.08 & 15 & 55.33 \\
\hline F43 & 18.25 & 22.41 & 19 & 48.83 \\
\hline F44 & 15.83 & 25.08 & 37 & 58.66 \\
\hline F45 & 37.25 & 42.41 & 13 & 46.5 \\
\hline F46 & 23.9 & 62.5 & 62 & 52.75 \\
\hline F47 & 48.46 & 75.83 & 37 & 43.58 \\
\hline F48 & 49.33 & 70.91 & 31 & 59.66 \\
\hline F49 & 53.83 & 72.66 & 26 & 52.41 \\
\hline F50 & 26.25 & 46.75 & 44 & 51.08 \\
\hline F51 & 26.83 & 40.33 & 34 & 50.5 \\
\hline
\end{tabular}


Agric. Biol. J. N. Am., 2011, 2(4): 584-590

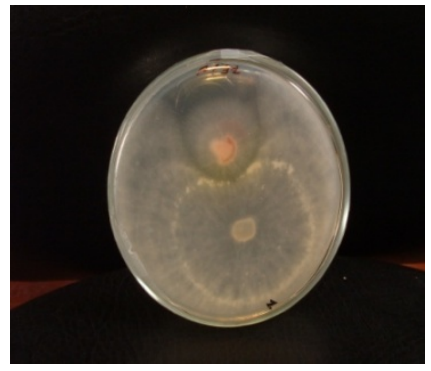

a: colony of Fusarium roseum

in the presence of Trichoderma viride

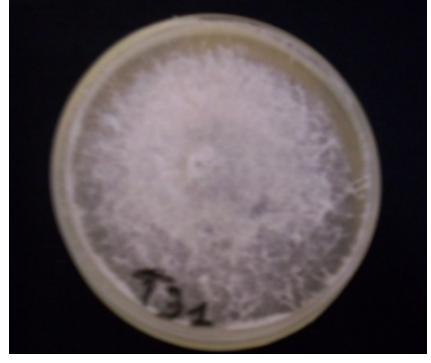

b: control of Fusarium roseum

after six days of incubation

Fig 2: Inhibitory effect of Trichoderma viride on mycelial growth Fusarium roseum

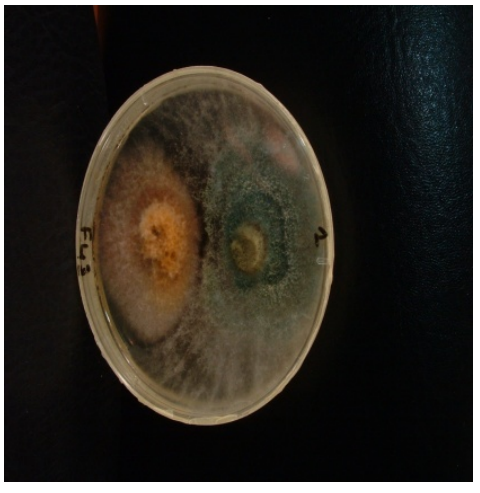

a: colony of Epicoccum sp1in the presence of Trichoderma viride

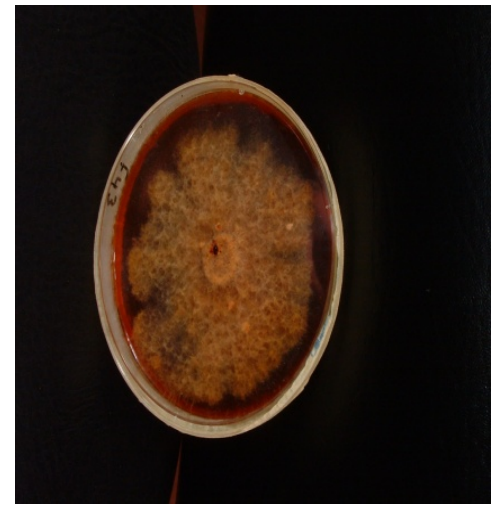

b: control of Epicoccum sp1

after six days of incubation

Fig3: Test on PDA of direct confrontation between Trichoderma viride and the strain of Epicoccum sp1 


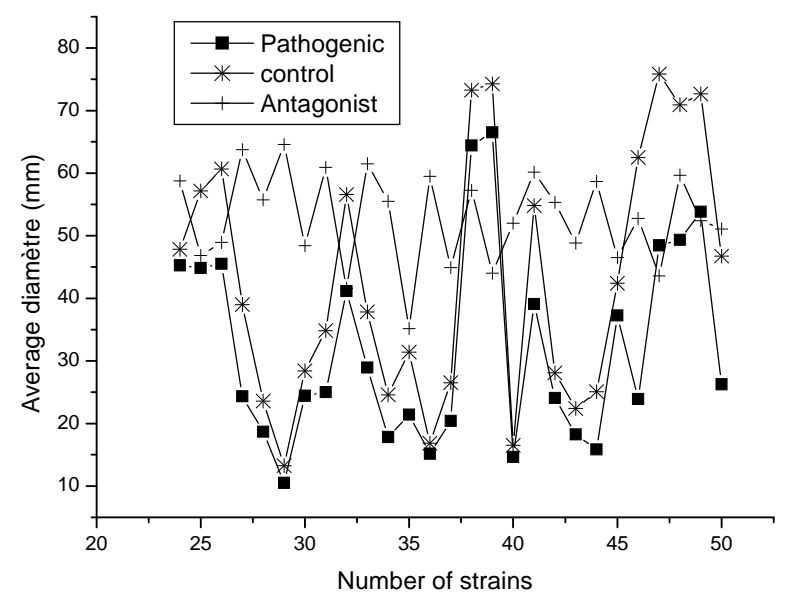

Fig 4: Average diameter $(\mathrm{mm})$ of colonies of pathogens face Trichoderma viride Compared with the control after six days of incubation

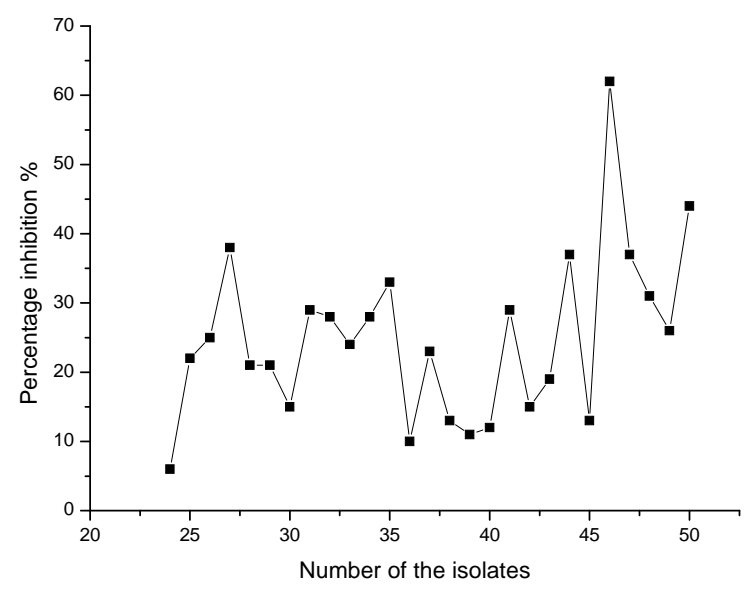

Fig 5: Percentage of inhibition of fungal isolates (technique of direct confrontation)

Similarly, Comporta (1985) demonstrated the inhibitory effect of Trichoderma $\mathrm{sp}$ between Rhizoctonia solani, while Howell (2003) found the mechanism of biocontrol by Trichoderma sp used to fight against diseases.

(Cundom and al. 2000) observed the invasion of the colony of the pathogen by Trichoderma harzianum by performing in vitro competition between the antagonist and Sclerotina sclerotium; too (Benhamou and Chet 1997) conducted a direct confrontation between Trichoderma harzianum and a soil fungus Fusarium oxysporium on a culture medium (PDA). (Harman and al. 2004) have written the action of Trichoderma sp mycoparasitism on pathogens, it is attached, wrapped around the pathogens and product peptaible which facilitate the entry of hyphae of Trichoderma $s p$ in the lumen parasitic mold. Furthermore (Pates and al. 1999) found that the strain of Trichoderma viride has an important activity to secrete enzymes for end to attack or remove mycotoxins synthesized by the pathogens.

CONCLUSION: Cereals are the raw materials more susceptible to fungal contamination. Our study resulted in isolation and identification of fungal flora affecting various organs of maize grown in Algeria (region of Jijel), with a high prevalence of fungal species from the genus: Phoma, Ulocladium, Fusarium, Pythium, Epicoccum, Melanconium and Trichoderma

Depending on the plant, Trichoderma is effective against most pathogens tested. Trichoderma grows rapidly on a culture medium, which should benefit during the confrontation. Indeed, tests of Trichoderma viride and confrontation between different fungal isolates, which directly on culture medium, we found an inhibition of mycelial growth of the pathogen tested. If there is direct contact between the two fungi, Trichoderma viride invaded colonies of fungal isolates sporulated and there even after six days of confrontation.

\section{REFERENCES}

Antal, Z ., Manczinger, L ., Szakacs, G ., Tengerdy, RP ., Ferency, L . 2000. Augmentation de la colonie, in vitro antagoniste et secretion d'enzymes de l'extracellulaire dans tensions froid tolérantes d'espèce Trichoderma Mycol Rés 104: 545-549.

Benhamou, N., Chet, I. 1997. Cellular and molecular mechanism involed in the interaction between Trichoderma harzianum and Pythium ultimium. Appl. Enviro. Microbial. 63, p .2095-2099.

Benitez, T., Delgado -Diorama, J., Rincon, A., Rey, M., Limon, C. 1998. Biofungicides: Trichoderma as a biocontrol against phytopathogenic fungi. Recent Ress. Dev .Microbiol, 1998, 2(1), 129-150

Botton, B., Bretton, A., Fevre, M ., Guy, Ph., Larpent, J. P., and Veau, P. 1985. Moisissures utiles et nuisibles, 
Importance industrielle (eds). Masson, Paris, New York, Milan, Mexico.

Bouchet, J. Guignard, J-L ., Pouchus, Y. and Villard, J. 2005. Les champignons: mycologie fondamentale appliquée. Paris : Masson, 2005, pp. 109-112,191p.

Champion, R. 1997. Identifier les champignons transmis par les semences INRA, Paris, 398p

Chase, A.1987. Compendium of ornamental foliage plant diseases. American phytopathological society, 92p

Chet, I.1987. Trichoderma application, mode of action, and potential as a biocontrol agent of soil borne plant pathogenic fungi. In: innovative approaches to plant disease control

(Chet I, Ed) New York: John Wiley and Sons. 1987.

Comporta, P. 1985. Antagonisme in vitro de Trichoderma spp. vis-à-vis de Rhizoctonia solani Kuhn. Agronomies 5, 613-620.

Christensen, C.M. 1957.Rev, 23,108.

Christensen, C.M. 1964. In mycotoxin in foods, edited by G.N.Wogan, published by Mit press, Cambridge, Massachusetts.

Christensen, C.M., Microcha, C.J. and Merounuck, R.A. 1977. Molds, mycotoxin and mycotoxicose.

Cundon, M.A., Mazza Mazzanti, S de Castanon and Gutierrez, S.A. 2000. Actividad antagonitica in vitro deaislamientos de Trichoderma harzianum, sobre exlerocios de Sclerotinia sclerotium. Communication Cientificas y Tecnologicas. Universitad National Del Nordeste, Facultad de Ciencias Agrarias-UNNE. Sargento cabral, corrientes, Argentina.

Davet, P. and Rouxel, F. 1997. Détection et isolement des champignons du sol. Techniques et pratiques. Edition INRA. Paris.

Dhingra, O.D., et Sinclair, J.B. 1995. Basic plant pathology. Methods $.2^{\text {nd }}$ edition. Lewis publishers, Boca Raton, 448pp.

Frisvard, J.C. and Samson, R.A. 1991. Filamentous fungi in foods and feeds: ecology, spoilage and mycotoxin production, Handbook of applied mycology, volume 3, foods and feeds, Dekker, M. New York: Arora, D.K., Mukerji, K. G and Marth. E.H., pp31-68
Gaetan LeFloch., Jessica Vallance., George Barbien., Patrice Rey.2006.Détection de Pythium oligondrum, agent de lute biologique, en culture hors sol de tomate12eme colloquée national de la recherché en IVT, Brest, 1-2.Juin 2006.

Gams, W., Bisset, J. 1998. Morphology and identification of Trichoderma.In: Kubicek cp, Harman GE (Eds Trichoderma and Gliocladium, vol1.Taulor and Francis, London, UK pp3-33.

Gevres, H.O. 1975. Anew major gene for resistance to Helminthosporium turcium leaf blight of maize. Plant disrep 59:296-300.

Guraud, J.P. 1998. Microbiologie alimentaire. Dunod. Paris. ISBN: 2100036661

Harman, GE ., Howel, CR ., Viterbo, UN ., Chet, Je ., Mlorito. 2004. Trichoderma espèce- opportuniste, les avirulent plantent des symbiotes. La nature en examene $2: 43-56$.

Howell, CR. 2003.Mécanismes employés par les espèces de Trichoderma dans le contrôle biologique de maladies de la plante historique et évolution de concepts courants plantes Dis87 :4-10.

Le Floch ; Rey ,P ; Benizri ,E ; Benhamou ,N .and Tirilly, Y. 2003a. The impact of auxin compounds produced by the antagonistic fungus, Pythium group $F$ on plant growth, plant soil, 257:457-470.

Marjoline Verscheure ., Georges Lognay ., Michel Marlier. 2002. Les méthodes chimiques d'identification et de classification des champignons Bioéthanol .Agron .Soc .Environ-2002 6(3)-131-142.

Pates, E., Meredith, F., Smart, W., Bacon, CW., Jaworski, AJ.1999. Trichoderma viride suppresses de fumonisin B1 production by Fusarium moniliforme. J Food protects 66:1326-1332(1999).

Prusky, D., Yakoby, N. 2003. Moisissures pathogènes: mener ou a mené par pH ambiant? Mol plant pathol4 :509-510.

Roquebert, M-F.1996. Interaction antagonistes de Trichoderma $s p$ dans les systèmes tellurique: systématique compte-rendu de 4 eme rencontre en Toxicologie, Paris, 1996, 13-15. 